\title{
EFFECTS OF KEFIR GRAINS ON FERMENTATION AND BIOACTIVITY OF GOAT MILK
}

\author{
- Research paper - \\ Xiaoyu SHI, He CHEN ${ }^{1}$, Yilin LI, Jie HUANG, Yunxia HE \\ School of Food and Biological Engineering, Shaanxi University of Science \& Technology, \\ Xi'an, 710021, China
}

\begin{abstract}
The effects of kefir grains from different regions in China on fermentation and bioactivity were studied by using $\mathrm{pH}$ value, acidity degree, protein hydrolysis degree, antioxidant activity, angiotensin converting enzyme (ACE, EC 3.4.15.1) inhibition rate and sensory evaluation as indexes to select the most suitable kefir grains as starter for goat milk. The parameters of kefir fermented goat milk were optimized by single factor experiment constantly. The results showed that kefir grain K1, which performed better in antioxidant activity, ACE inhibitory activity than the other four kefir grains and sensory evaluation was inferior to kefir grain $\mathrm{K} 5$ only, was suitable for the fermentation of goat milk. And the optimum fermentation conditions were found to be as $3 \%$ inoculation size at $25^{\circ} \mathrm{C}$ for $22 \mathrm{~h}$.
\end{abstract}

Keywords: ACE inhibitory activity; antioxidant activity; goat milk; kefir grain

\section{INTRODUCTION}

Kefir is an ancient fermented milk product with refreshing sour taste and aroma, originating from the North Caucasus Mountains of Russia. It has been popular in Russia and central Asian countries such as Kazakhstan and Kyrgyzstan for centuries (Otles et al., 2003). And kefir has gradually spread to Japan, the United States and some European countries (Ahmed et al., 2013), which is becoming one of the most popular fermented milk products currently. Milk are employed as a main material fermented by a kind of irregular granular starter culture, denominated kefir grain, to make kefir. Kefir grains are milky white to creamy and formed naturally. The complex folded surface makes it look like cauliflower at the size of $0.5-3.5 \mathrm{~cm}$ in diameter (Farnworth, 2006). As a living organism in which natural immobilized microorganisms coexist, some lactic acid bacteria, acetic acid bacteria and yeasts are grown in kefir grains. These bacteria and yeasts are surrounded by a water-soluble polysaccharide matrix, which been named as kefiran (Enikeev, 2012; Hsieh et al., 2012; Irigoyen et al., 2005).

A mixture of flavor substances such as lactic acid, ethanol, carbon dioxide, acetaldehyde is formed since the lactate fermentation and alcohol fermentation of lactose take place simultaneously in the process of kefir production (Güzelseydim et al., 2000). Kefir fermented milk not only possesses a unique taste, but also has many a variety of probiotic functions. Probiotic and prebiotic properties, antimicrobial properties, anticarcinogenic properties, antidiabetic properties, antiallergic properties are verified in many researches (Güzelseydim et al., 2011), which mainly due to nutrients in liquid milk itself and metabolites secreted by microorganisms. There is evidence that one of the reasons for the general longevity of the population in the Caucasus is the long-term consumption of kefir fermented milk products.

For a long time, owing to distinguishing growth and metabolic environment in different regions, so do proliferation methods, diversity of kefir grain is observed inevitably. Compared to other

${ }^{1}$ Corresponding author. Mailing address: chenhe419@gmail.com 
dairy, goat milk has an unparalleled advantage, in which nutrients such as protein, fat, minerals, vitamins are in higher levels than other milk (Belewu et al., 2002, Park et al., 2007, Lópezaliaga et al., 2010). The overall protein particles of goat milk is small and fat are composed of short-chain fatty acids. Thus, screening of suitable starter culture for goat milk fermentation is very necessary. In the present study, kefir grains were employed as starters to

\section{MATERIALS AND METHODS}

Strains: Kefir grains (K1, K2, K3, K4, K5) were collected from different regions in China and preserved by the school of Food and Biological Engineering, Shaanxi University of Science \& Technology (Xi' an, China).

Preparation of kefir: Kefir grain was used as starter to ferment reconstituted skim goat milk pasteurized with $2 \%$ inoculum. It was incubated at $25^{\circ} \mathrm{C}$ for $22 \mathrm{~h}$.

Determination of $\mathbf{p H}$ : The $\mathrm{pH}$ was measured using $\mathrm{pH}$ meter (Shanghai INESA Instruments Co., Ltd, Shanghai, China).

Determination of acidity: Acidity was using standard sodium hydroxide $(0.1 \mathrm{~mol} / \mathrm{L})$ titration.

Determination of protein hydrolysis degree: The degree of protein hydrolysis (DH) was measured using $\mathrm{pH}$-state. It was conducted in triplicate.

Determination of DPPH free radical scavenging capacity: Kefir were collected, adjusted $\mathrm{pH}$, vigorously stirred, and centrifuged at $8000 \mathrm{rpm} / \mathrm{min}$ for $15 \mathrm{~min}$ to obtain the corresponding whey fractions. $1 \mathrm{ml}$ whey fractions were mixed with $1 \mathrm{ml}$ ethanol solution containing $0.1 \mathrm{mmol} / \mathrm{L} \quad \mathrm{DPPH}$ radical. Absorbance was measured at $517 \mathrm{~nm}$ after dark reaction. The DPPH radical scavenging rate was calculated by using the following equation:

$\mathrm{DPPH}$ free radical scavenging rate $=(1$ $\left.\mathrm{A}_{1} / \mathrm{A}_{2}\right) \times 100 \%$ (1)

All the DPPH free radical scavenging capacity were measured in triplicate.

Where $A_{1}$ is the absorbance of the control, $A_{2}$ is the absorbance of the compared.

Determination of the capacity to chelating effect: $1 \mathrm{ml}$ whey fractions were taken and add $3.7 \mathrm{~mL}$ distilled water, $0.1 \mathrm{~mL} 3 \mathrm{mmol} / \mathrm{L}$ ferrous ferment goat milk. The effects of kefir grains from different regions on the biological activities of fermented product were studied. Fermentation conditions (temperature, fermentation time, inoculation size) were optimized by single factor experiment constantly after selecting the most suitable kefir grains as fermenter for goat milk. It provided a reference for the subsequent development of the kefir goat's milk product.

chloride solution, $0.2 \mathrm{~mL} 5 \mathrm{mmol} / \mathrm{L}$ phenanthroline solution, respectively. The absorbance of samples was measured at $562 \mathrm{~nm}$ after fully reaction. The chelating effect was calculated as the following equation:

Chelating effect $=\left(\mathrm{A}_{b}-\mathrm{A}_{\mathrm{a}}\right) / \mathrm{A}_{\mathrm{b}} \times 100 \%$ (2)

All the chelating effect were measured in triplicate.

Where $A_{b}$ is the absorbance of the control, $A_{a}$ is the absorbance of the compared.

Determination of ACE inhibitory activity: 100 $\mu \mathrm{L}$ whey fractions were added with $20 \mu \mathrm{L} 0.1$ $\mathrm{UN} / \mathrm{mL}$ ACE and $200 \mu \mathrm{L} 5 \mathrm{mmol} / \mathrm{L}$ HHL solution. $250 \mathrm{~mL} 1 \mathrm{~mol} / \mathrm{L} \mathrm{HCl}$ was provided to terminate the reaction. The sample groups were added $1.7 \mathrm{~mL}$ ethyl acetate. $1 \mathrm{~mL}$ ethyl acetate layer was taken and dissolved in $3 \mathrm{~mL}$ deionized water after evaporated at $120^{\circ} \mathrm{C}$. The absorbance was measured at $228 \mathrm{~nm}$. The ACE inhibition rate was calculated as follow:

ACE inhibition rate $=\left(X_{1}-X_{2}\right) /\left(X_{1}-X_{3}\right) \times 100 \%(3)$ All the ACE inhibition rate were measured in triplicate.

Where $\mathrm{X}_{1}, \mathrm{X}_{2}, \mathrm{X}_{3}$ represent absorbance without the whey fraction, absorbance without ACE and the absorbance in the presence of both ACE and the whey fraction, respectively.

Sensory evaluation: Sensorial evaluation of kefir was carried out by a panel of 12 experienced assessors. $50 \mathrm{~mL}$ kefir was collected in glass and numbered randomly before evaluation. Assessors were asked to taste. Taste and smell (total score 40 ), state of the tissue (total score 50), color (total score 10) of samples were evaluated in turn. Overall score was calculated and done averaged.

Single factor experiment design: Temperature $\left(21{ }^{\circ} \mathrm{C}, 23{ }^{\circ} \mathrm{C}, 25{ }^{\circ} \mathrm{C}, 27{ }^{\circ} \mathrm{C}, 29^{\circ} \mathrm{C}\right)$, fermentation time (18h, 20h, 22h, 24h, 26h), inoculation size $(1 \%, 2 \%, 3 \%, 4 \%, 5 \%)$ were selected as factors 
of single factor experiment. Acidity degree, $\mathrm{pH}$ value, protein hydrolysis degree, ACE inhibitory activity and sensory evaluation of kefir were

\section{RESULTS AND DISCUSSIONS}

\section{Screening of suitable kefir grains for goat milk} fermentation

Five kinds of kefir grain were inoculated into pasteurized skim goat milk at inoculation size of measured under these conditions to optimize the parameters of kefir fermented goat milk.

$2 \%$ and fermented at $25^{\circ} \mathrm{C}$ for $22 \mathrm{~h}$, respectively. $\mathrm{pH}$ value, acidity degree, protein hydrolysis degree, antioxidant activity, ACE inhibitory activity and sensory evaluation of kefir were measured. The results were showed in Figure 1.
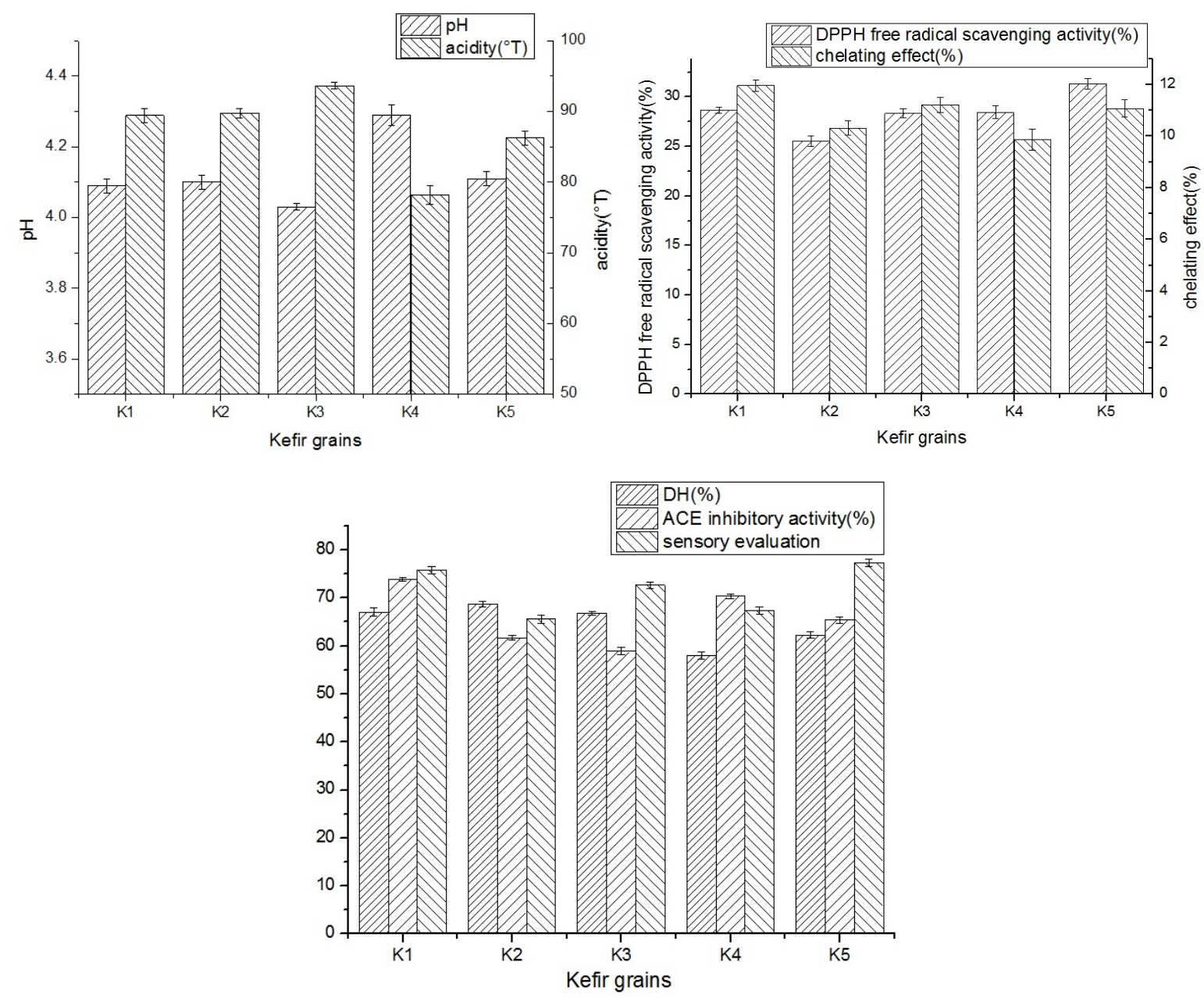

Figure 1 Effects of different kefir grains on the $\mathrm{pH}$, acidity (a), DPPH free radical scavenging activity, chelating effect (b), DH, ACE inhibitory activity and sensory evaluation (c) for fermented goat milk.

The error bars represent standard deviation of means $(n=3)$.

As shown in Figure 1, several indexes $(\mathrm{pH}$, acidity, DH, DPPH free radical scavenging activity, chelating effect, ACE inhibition rate, sensory evaluation) of the goat milk fermented by kefir grain $\mathrm{K} 1$ were obtained as $4.09 \pm 0.02$, $89.42 \pm 1.02{ }^{\circ} \mathrm{T}, \quad 67.02 \pm 0.84 \%, \quad 28.67 \pm 0.31 \%$, $11.97 \pm 0.22 \%, 73.83 \%, 75.83 \pm 0.77$, respectively, after incubation with $2 \%$ inoculum at $25^{\circ} \mathrm{C}$ for 22h. Both antioxidant activity and ACE inhibitory activity were superior to the other four kefir grains. Therefore, kefir grain K1 was more suitable for goat milk fermentation than other kefir grains and it was selected for further optimization. 
Effect of temperature on fermented goat milk by kefir grain $\mathrm{K} 1$

After the recovered goat milk was sterilized and cooled, the kefir grain K1 was employed to inoculate with $2 \%$ inoculum size and fermented at $21{ }^{\circ} \mathrm{C}, 23{ }^{\circ} \mathrm{C}, 25{ }^{\circ} \mathrm{C}, 27{ }^{\circ} \mathrm{C}$ and $29^{\circ} \mathrm{C}$ for 22 hours, respectively. $\mathrm{pH}$, acidity, $\mathrm{DH}, \mathrm{ACE}$ inhibition rate and sensory evaluation of samples were measured. And the results were showed in Figure 2. With the increased of fermentation temperature, the $\mathrm{pH}$ decreased continuously changed at a range of 4.25 to 3.89 . The acidity kept rising from $73.24^{\circ} \mathrm{T}$ to $94.13^{\circ} \mathrm{T}$. DH increased rapidly from $58.01 \%$ to $68.47 \%$ at the temperature range of $21^{\circ} \mathrm{C}$ to $25^{\circ} \mathrm{C}$ and it increased slowly after $25^{\circ} \mathrm{C}$. The ACE inhibition rate increased rapidly from $54.95 \%$ to $72.37 \%$. Afterwards, the ACE inhibitory activity increased slowly with the increase of temperature. The maximum of ACE inhibition rate was obtained at $29{ }^{\circ} \mathrm{C}$ as $73.56 \%$. Temperature had a significant effect on the sensory evaluation of kefir fermented goat milk. With the score increasing first and then decreasing, it reached the highest value at $25{ }^{\circ} \mathrm{C}$. By comparing the effects of temperature on the $\mathrm{pH}$ value, acidity, proteolytic degree, ACE inhibitory activity and sensory evaluation of Kefir fermented goat milk, $25{ }^{\circ} \mathrm{C}$ was selected for subsequent response surface optimization.

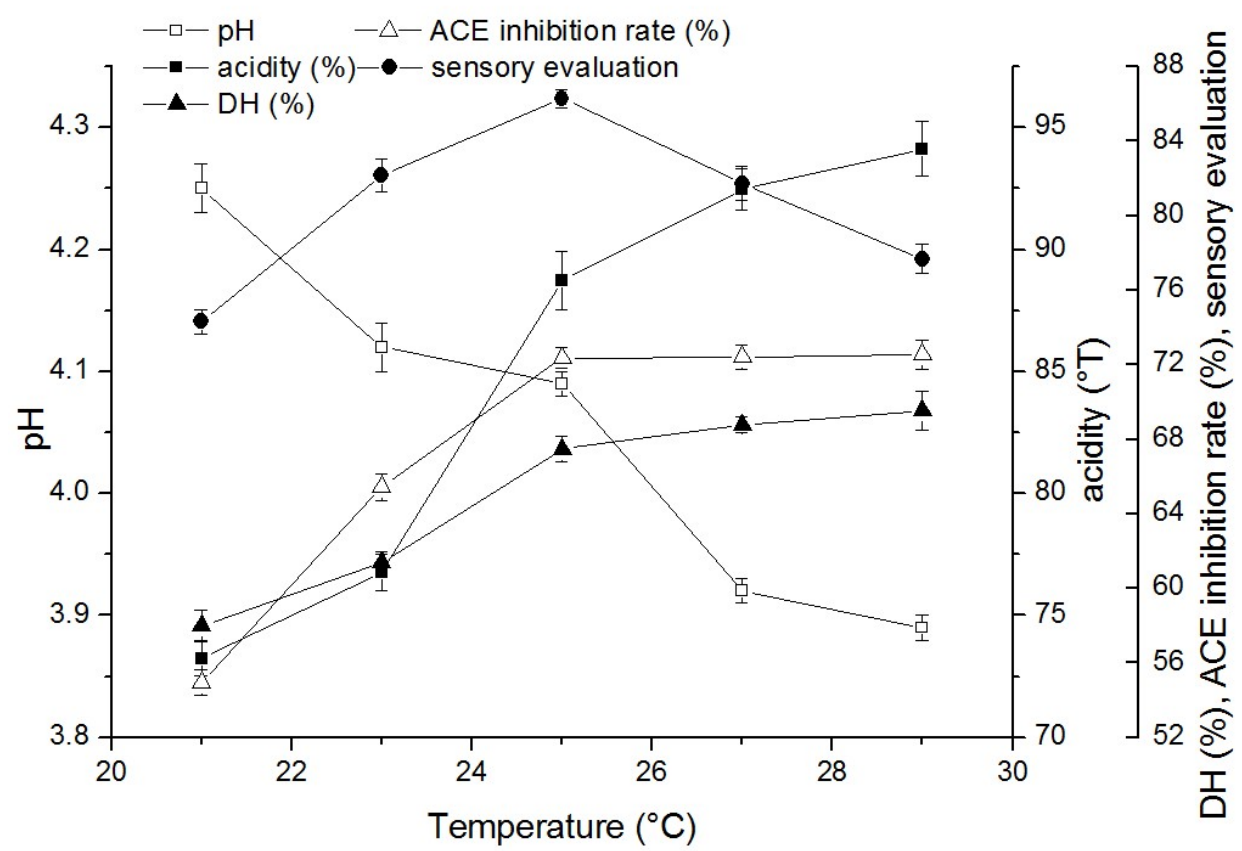

Figure 2. Effects of temperature on the $\mathrm{pH}$, acidity, degree of hydrolysis, ACE inhibition rate and sensory evaluation of kefir. The error bars represent standard deviation of means $(n=3)$.

\section{Effect of fermentation time on fermented goat milk by kefir grain $\mathrm{K} 1$}

Kefir grain K1 was inoculated into pasteurized skim goat milk reconstituted at inoculation size of $2 \%$ and fermented at $25^{\circ} \mathrm{C}$ for $18 \mathrm{~h}, 20 \mathrm{~h}, 22 \mathrm{~h}, 24 \mathrm{~h}$ and 26h, respectively. $\mathrm{pH}$, acidity, $\mathrm{DH}, \mathrm{ACE}$ inhibition rate and sensory evaluation of sample were measured and the results as shown in Figure 3. $\mathrm{pH}$ of kefir fermented goat milk decreased continuously from 4.22 to 3.99 during the fermentation period of 18 to 26 hours. The acidity increased rapidly within 18 to 20 hours. And the growth rate tended to be gentle after 20 hours, which reached to $87.02{ }^{\circ} \mathrm{T}$ at the end of the fermentation. DH had the same tendency as acidity. It increased rapidly from $55.75 \%$ to $66.89 \%$ in 18 to 22 hours. After 22 hours, the growth rate tended to be flat. ACE inhibitory activity increased rapidly from $72.03 \%$ to $72.88 \%$ within 18 to 20 hours. After 22 hours, growth rate tended to be stable and it reached finally $73.21 \%$. Fermentation time had a significant effect on the kefir sensory evaluation as well, with the score increasing first and then decreasing, reaching a maximum of 81 at $22 \mathrm{~h}$. Therefore, 22 hours was selected for further optimization. 


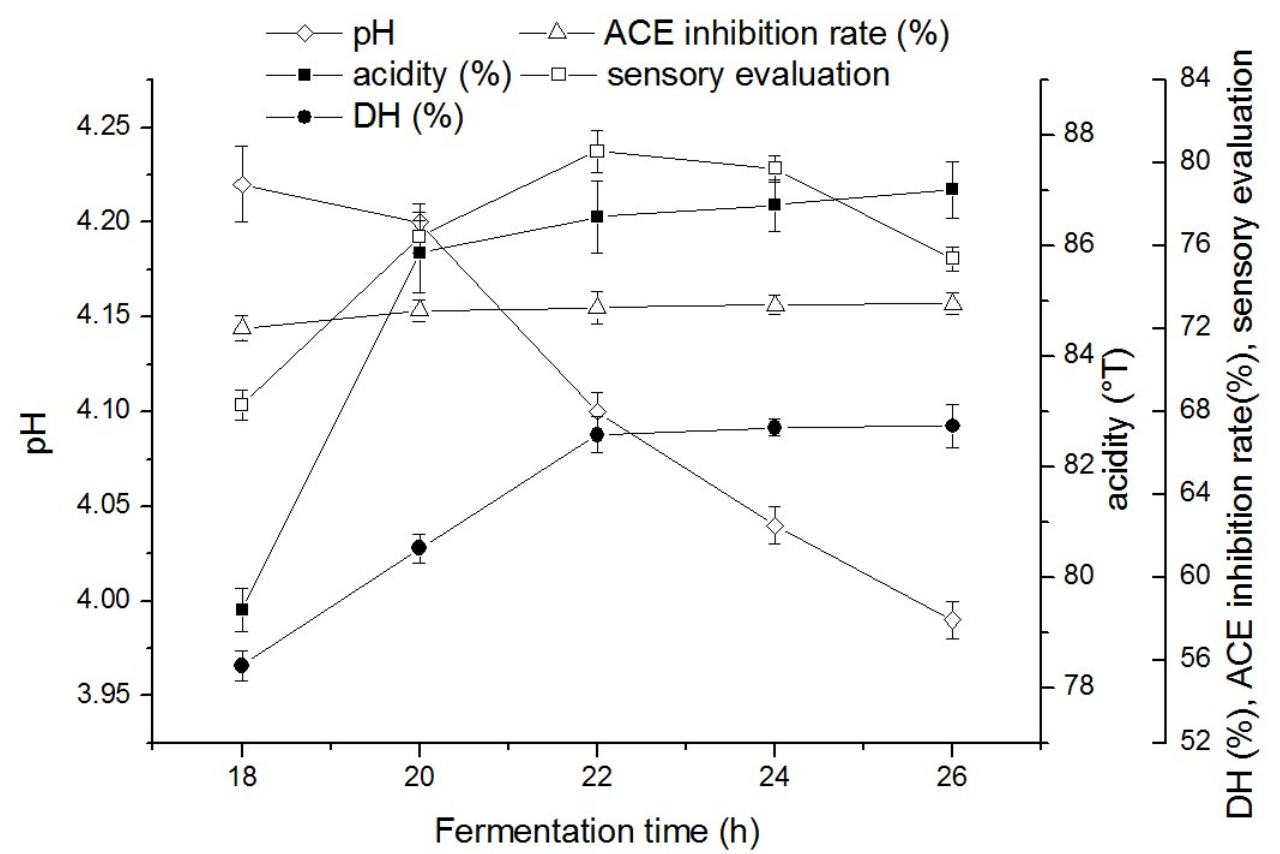

Figure 3 Effects of fermentation time on the $\mathrm{pH}$, acidity, degree of hydrolysis, ACE inhibition rate and sensory evaluation of kefir. The error bars represent standard deviation of means $(n=3)$.

Effect of inoculation size on fermented goat milk by kefir grain $\mathrm{K} 1$

Kefir grain $\mathrm{K} 1$ was inoculated into sterilized goat milk with $1 \%, 2 \%, 3 \%, 4 \%$ and $5 \%$ inoculum, separately, and fermented at $25{ }^{\circ} \mathrm{C}$ for 22 hours. The $\mathrm{pH}$, acidity, $\mathrm{DH}, \mathrm{ACE}$ inhibition rate and sensory evaluation of samples were measured, and the results showed in Figure 4.

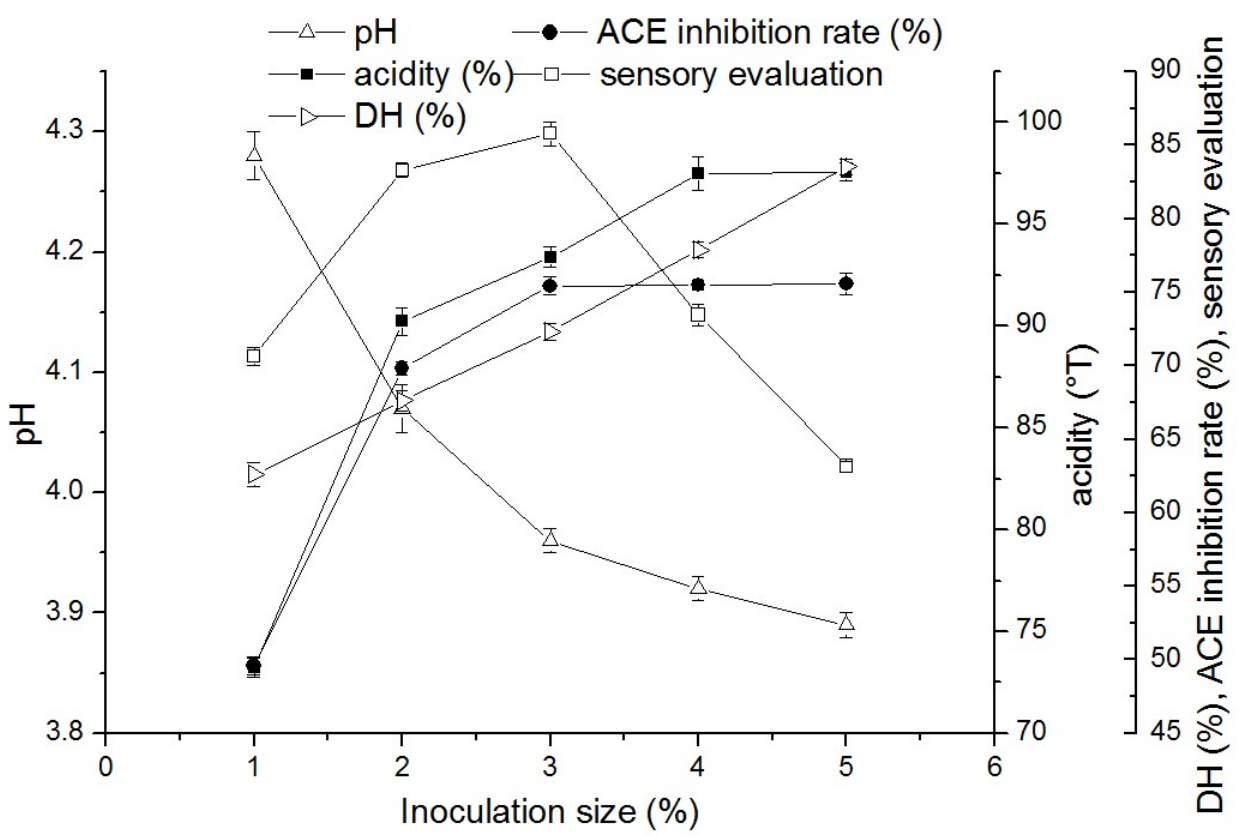

Figure 4 Effects of inoculation size on the $\mathrm{pH}$, acidity, degree of hydrolysis, ACE inhibition rate and sensory evaluation of kefir. The error bars represent standard deviation of means $(n=3)$.

As shown in Figure 4, with the increase of inoculation size, the $\mathrm{pH}$ decreased continuously, while the acidity continued to increase. The lowest $\mathrm{pH}$ was 3.89 and the highest acidity was
$97.58{ }^{\circ} \mathrm{T}$ when inoculated with $5 \%$. As the inoculum size increased, DH changed from $62.21 \%$ to $83.54 \%$ with a linear increase. The ACE inhibition rate increased rapidly from $49.61 \%$ to 
$75.42 \%$ in the range of $1 \%$ to $3 \%$. After that, the ACE inhibitory activity increased steadily and slowly. The largest ACE inhibition rate, 75.56\%, was obtained when it was inoculated with $5 \%$. The inoculation size significantly affected the sensory evaluation of kefir fermented goat milk, with the score increasing first and then decreasing. The highest value was got at 3\% inoculation size.

\section{Discussion}

Kefir grain is a complex mixture of abundant lactic acid bacteria, yeasts and acetic acid bacteria (Arslan, 2015). The presence of various bacteria and yeasts in kefir leads to lactic acid and alcohol fermentation of lactose during incubation. Microbial diversity of kefir grain can be owing to distinct environments and culture incubation methods in different regions, which results to the distinctness of fermentation process and bioactivity for kefir. Besides, the protein source also has effect on quality of kefir. The value of $\mathrm{pH}$ reached to 4.28 and proteolytic activity was $64.4 \pm 0.8 \%$ when made kefir using cow milk (DiNkçİ et al., 2015). Proteolytic activity exhibited obvious differences ranged from $58.01 \%$ to $68.7 \%$ when using kefir grains from different region in this study. Appreciable proteolytic activity was measured in all kefir samples which suggested proliferation of kefir grain being dependent on a proteolytic system.

It can release lots of functional peptides with bioactivity from milk source protein during fermentation. It has been reported that the biological activity of hydrolysate increased significantly as the DH increased (Lee et al., 2008). Antioxidant properties can be assessed by both DPPH free radical scavenging activity and chelating effect, which were lower than other research (Liu et al., 2005). The fact could be

\section{CONCLUSIONS}

$\mathrm{pH}$ value, acidity, degree of protein hydrolysis, DPPH free radical scavenging activity, chelating effect, ACE inhibitory activity, sensory evaluation of fermented milk were measured using five different kinds of kefir grains to ferment goat milk under the same conditions. The attributed to the origins of kefir grain and differences between measure methods. Moreover, it was found that duration of fermentation had a significant effect on the increase in antioxidant activity (Monajjemi et al., 2012). ACE inhibition rate were ranged from $58.88 \%$ to $73.83 \%$. Thence, kefir fermented goat milk could be applied for anti-hypertension. It was reported that the value of whey kefir was run up to $73.07 \pm 0.91 \%$ (Febrisiantosa et al., 2013). The high ACE inhibitory activity determined in kefir could be owing to the combined action of several strains of lactic acid bacteria and yeast during goat milk incubation (Quirós et al., 2005).

Studies have shown that fermentation conditions have a significant impact on the quality of kefir. A research by Schoevers et al. (2003) showed that the best proliferation for kefir grains was obtained at $25^{\circ} \mathrm{C}$, which was consistent with the results of this paper. In fact, the effect of temperature on the quality of kefir can be attributed to the influence of temperature on the growth of bacteria and yeasts in kefir grains. In other words, microbial proliferation required a suitable temperature. Inoculation size and fermentation time are also viewed as the effect factors. The results of the distinguishing studies may show some differences due to the diversity of kefir grains. Köktaş et al. (2003) found that optimal inoculation rates for kefir grains were $2 \%$.

Kefir has become an important functional dairy food since health benefits were possessed. Kefir grains have extensive uses in food products worldwide, such as whey-based kefir beverages (Magalhães et al., 2011), white pickled cheese (Goncu et al., 2005), sourdough bread (Plessas et al., 2011), beer (Rodrigues et al., 2016). Screening of kefir grains from different regions can provide a reference for the development of kefir goat milk functional products.

results indicated kefir grain K1 was more suitable for goat milk fermentation. Fermentation conditions were optimized by single factor experiments. The optimum fermentation conditions for kefir grain $\mathrm{K} 1$ were found to be as $3 \%$ inoculation size at $25{ }^{\circ} \mathrm{C}$ for $22 \mathrm{~h}$, which provided a reference for the subsequent production of kefir fermented goat milk. 


\section{ACKNOWLEDGEMENTS}

The work was partly supported by the key industry innovation chain project of Science and Technology Department of Shaanxi Province (No.2018ZDCXL-NY-01-01), the science and technology project of Xi' an city [2017050NC/NY007(1)] and Shaanxi Innovation and Transformation Project of Agricultural Science and Technology (No.NYKJ-2015-004).

\section{REFERENCES}

1. Ahmed, Z., Wang, Y., Ahmad, A., Khan, S. T., Nisa, M., \& Ahmad, H., et al. (2013). Kefir and health: a contemporary perspective. Critical Reviews in Food Science \& Nutrition, 53(5), 422-434.

2. Arslan, S. (2015). A review: chemical, microbiological and nutritional characteristics of kefir. CyTA - Journal of Food, 13(3), 340-345.

3. Awad, A. B., Downie, A., Fink, C. S., \& Kim, U. (2000). Dietary phytosterol inhibits the growth and metastasis of mda-mb-231 human breast cancer cells grown in scid mice. Anticancer Research, 20, 821-824.

4. Belewu, M. A., \& Aiyegbusi, O. F. (2002). Comparison of the mineral content and apparent biological value of milk from human, cow and goat. Journal of Food Technology in Africa, 7(1), 9-11.

5. DiNkçİ, N., Kesenkaş, H., Korel, F., \& Kınık, Ö. (2015). An innovative approach: cow/oat milk based kefir. Mljekarstvo, 65 (3), 177-186.

6. Enikeev, R. (2012). Development of a new method for determination of exopolysaccharide quantity in fermented milk products and its application in technology of kefir production. Food Chemistry, 134(4), 24372441.

7. Farnworth, E. R. (2006) Kefir-a complex probiotic. Food Science and Technology Bulletin: Fu, 2(1), 1-17.

8. Febrisiantosa, A., Purwanto, B. P., Arief, I. I., \& Widyastuti, Y. (2013). Physical, chemical and microbiological characteristics of whey kefir and its angiotensin converting enzyme (ace) inhibitory activity. Jurnal Teknologi Dan Industri Pangan, 24(2), 147-153.

9. Goncu, A., \& Alpkent, Z. (2005). Sensory and chemical properties of white pickled cheese produced using kefir, yoghurt or a commercial cheese culture as a starter. International Dairy Journal, 15, 771-776.

10. Güzelseydim, Z. B., Kok-Tas, T., Greene, A. K., \& Seydim, A. C. (2011). Review: functional properties of kefir. Critical Reviews in Food Science \& Nutrition, 51(3), 261-268.

11. Güzelseydim, Z. B., Seydim, A. C., Greene, A. K., \& Bodine, A. B. (2000). Determination of organic acids and volatile flavor substances in kefir during fermentation. Journal of Food Composition \& Analysis, 13(1), $35-43$.

12. Hsieh, H. H., Wang, S. Y., Chen, T. L., Huang, Y. L., \& Chen, M. J. (2012). Effects of cow's and goat's milk as fermentation media on the microbial ecology of sugary kefir grains. International Journal of Food Microbiology, 157(1), 73-81.

13. Irigoyen, A., Arana, I., Castiella, M., Torre, P., \& Ibáñez, F. C. (2005). Microbiological, physicochemical, and sensory characteristics of kefir during storage. Food Chemistry, 90(4), 613-620.

14. Köktaş, T., Seydim, A. C., Ozer, B., \& Guzel-Seydim, Z. B. (2013). Effects of different fermentation parameters on quality characteristics of kefir. Journal of Dairy Science, 96(2), 780-789.

15. Lee, J. S., Mi, A. Y., Koo, S. H., Baek, H. H., \& Lee, H. G. (2008). Antioxidant and ace inhibitory activities of soybean hydrolysates: effect of enzyme and degree of hydrolysis. Food Science \& Biotechnology, 17(4), 873-877.

16. Liu, J. R., Chen, M. J., \& Lin, C. W. (2005). Antimutagenic and antioxidant properties of milk-kefir and soymilk-kefir. Journal of Agricultural \& Food Chemistry, 53(7), 2467-2474.

17. Lópezaliaga, I., Díazcastro, J., Alférez, M. J. M., Barrionuevo, M., \& Campos, M. S. (2010). A review of the nutritional and health aspects of goat milk in cases of intestinal resection. Dairy Science \& Technology, 90(6), 611-622.

18. Magalhães, K. T., Dragone, G., Pereira, G. V. D. M., Oliveira, J. M., Domingues, L., \& Teixeira, J. A., et al. (2011). Comparative study of the biochemical changes and volatile compound formations during the production of novel whey-based kefir beverages and traditional milk kefir. Food Chemistry, 126(1), 249-253. 
19. Monajjemi, M., Aminin, A. L. N., Ilkhani, A. R., \& Mollaamin, F. (2012). Nano study of antioxidant activities of fermented soy whey prepared with lactic acid bacteria and kefir. African Journal of Microbiology Research, 6(2), 426-430.

20. Otles, S., Cagindi, O. (2003). Kefir: A probiotic dairy-composition, nutritional and therapeutic aspects. Pakistan Journal of Nutrition, 2, 54-59.

21. Park, Y. W., Juarez, M., Ramos, M., \& Haenlein, G. F. W. (2007). Physico-chemical characteristics of goat and sheep milk. Small Ruminant Research, 68(1), 88-113.

22. Plessas, S., Alexopoulos, A., Bekatorou, A., Mantzourani, I., Koutinas, A. A., \& Bezirtzoglou, E. (2011). Examination of freshness degradation of sourdough bread made with kefir through monitoring the aroma volatile composition during storage. Food Chemistry, 124(2), 627-633.

23. Quirós, A., Hernándezledesma, B., Ramos, M., Amigo, L., \& Recio, I. (2005). Angiotensin-converting enzyme inhibitory activity of peptides derived from caprine kefir. Journal of Dairy Science, 88(10), 34803487.

24. Rodrigues, K. L., Araújo, T. H., Schneedorf, J. M., Ferreira, C. D. S., Moraes, G. D. O. I., \& Coimbra, R. S., et al. (2016). A novel beer fermented by kefir enhances anti-inflammatory and anti-ulcerogenic activities found isolated in its constituents. Journal of Functional Foods, 21, 58-69.

25. Schoevers, A., \& Britz, T. J. (2003). Influence of different culturing conditions on kefir grain increase. International Journal of Dairy Technology, 56(3), 183-187. 